\title{
Adsorption Studies of Cd (II) from Water by Acid Modified Multiwalled Carbon Nanotubes
}

\author{
Magda A AkI ${ }^{1 *}$ and Ali M Abou-Elanwar ${ }^{2}$ \\ ${ }^{1}$ Chemistry Department, Faculty of Science, Mansorua University, Egypt \\ ${ }^{2}$ National Research Centre, Dokki, Giza, Egypt
}

\begin{abstract}
This work aims to decorate carbon nanotubes with oxygenated functional groups for effective removal of Cadmium ions from aqueous media. For that purpose Carbon nanotubes (CNT) was oxidized by nitric acid to give MCNT- $\mathrm{HNO}_{3}$. The CNT and MCNT- $\mathrm{HNO}_{3}$ were characterized by SEM, TEM, FT-IR, Boehm titration, nitrogen adsorption-desorption analysis, point of zero charge and surface $\mathrm{pH}$. The adsorption experiments of $\mathrm{Cd}(\mathrm{II})$ onto sorbents were studied using the batch technique and factors affecting the adsorption capacities of $\mathrm{Cd}(\mathrm{II})$ were investigated and discussed. The isotherm data were analyzed using Langmuir and Freundlich equations. The equilibrium data fitted well Langmuir isotherm for both CNT and MCNT- HNO . The kinetic results were analyzed using pseudo-first order, pseudo-second order, intraparticle diffusion and the Boyd equations. The rate constants, equilibrium capacities and related correlation coefficients $\left(R^{2}\right)$ for each kinetic model were calculated and discussed. Highest values of $R^{2}$ were obtained on applying the pseudo second-order with both carbons. Although intraparticle diffusion plays impotent role in rate-controlling step in the adsorption process of $\mathrm{Cd}(\mathrm{II})$ onto the investigated sorbents, film diffusion is also controlling this process. The thermodynamic parameters including $\Delta \mathrm{G}^{\circ}, \Delta \mathrm{H}^{\circ}$ and $\Delta \mathrm{S}^{\circ}$ for the adsorption processes of $\mathrm{Cd}$ (II) on the carbons were calculated, and the negative value of $\Delta \mathrm{G}^{\circ}$ indicated the spontaneous nature of adsorption. The desorption studies revealed that the regeneration of $\mathrm{MCNT}-\mathrm{HNO}_{3}$ can be easily achieved.
\end{abstract}

Keywords: Carbon nanotubes; Water; Pollution; Adsorption; Cd(II); FAAS; Nitric acid

\section{Introduction}

Heavy metal pollution is a serious ecological issue due to its harmful impacts and accumulation throughout the food chain and therefore in the human body. Cadmium is considered as one of the highly hazardous heavy metal pollutants whereas Cadmium is listed as the $7^{\text {th }}$ most hazardous substance by The Agency for Toxic Substances and Disease Registry [1]. A number of acute and chronic disorders caused by $\mathrm{Cd}(\mathrm{II})$ exposure, such as itai-itai disease, renal damage, emphysema, hypertension and testicular atrophy [2]. It is likely that cadmium toxicity is related to its strong tendency to form bonds with thiol functional groups in certain enzymes which results in the displacement of biologically essential metals [3]. Cadmium enter the aquatic environment through a number of diverse ways involving erosion of natural deposits, metal refinery discharges, and electronic waste runoff $[1,4,5]$. To keep water healthy the $\mathrm{Cd}(\mathrm{II})$ should be kept under certain limits. The permissible limit for Cd(II), given by Environmental Protection Agency (EPA), is $0.005 \mathrm{mg} / \mathrm{l}$ and the current guideline value of drinking water described by the World Health Organization (WHO) is $0.003 \mathrm{mg} / \mathrm{l}[4,6]$ hence $\mathrm{Cd}(\mathrm{II})$ should not exceed these limits to keep water hazardless. Decontaminate of cadmium ions from waste water can be achieved by applying various conventional techniques that are usually recognized as inefficient and/ or expensive [7]. Adsorption is one of the highly efficient methodology for heavy metal removal [8]. The urgent demands for improving the quality of potable water has motivated researchers to modify a new highly effective adsorbents. Carbon nanotubes (CNTs), brilliant new carbon's form, are latest researchable area since their discovery [9] due to their amazing mechanical features [10], great chemical stability, extraordinary electrical property [11] and large specific surface area [12]. The outstanding properties of CNTs qualified them for new application such as hydrogen storage, quantum nanowires, catalyst supports and chemical sensors [13-16]. One of the most hopeful uses of CNTs is the removal pollutants from water where CNTs have shown exceptional efficiency for the removal of many organic, inorganic and radioactive contaminants [17-22]. The present study targets to modify the surface of CNTs with functional groups using nitric acid as oxidizing agent to improve their capability for removing of Cd(II) from water. The parameters such as $\mathrm{pH}$, contact time, initial concentration and adsorbent dose were examined. Adsorption isotherms, adsorption kinetics, and thermodynamic parameters of $\mathrm{Cd}(\mathrm{II})$ adsorption have been investigated. The equilibrium adsorption data are inspected by both Freundlich and Langmuir isotherm models. The desorption studies of CNTs were also executed.

\section{Material and Methods}

\section{Reagents and solutions}

The analytical grade reagents were purchased from Sigma-Aldrich. A stock solution of $1000 \mathrm{ppm}$ Cd(II) was prepared by dissolving 1.7909 $\mathrm{g}$ of $\mathrm{CdCl}_{2} \cdot 2 \mathrm{H}_{2} \mathrm{O}$ in acidified doubled distilled water and diluted to 1000 $\mathrm{ml}$ by doubled distilled water. Acetate buffer $(\mathrm{pH}=5.5)$ was made using acetic acid and $\mathrm{NaOH}$ solution, to be used in this study. $\mathrm{CH}_{3} \mathrm{COOH}$, $\mathrm{HNO}_{3}, \mathrm{HCl}$ and $\mathrm{NaOH}$ were purchased from Merck and used without further purification.

\section{Apparatus}

The $\mathrm{pH}$ measurements were made using a $\mathrm{pH}$ meter (Hi 931401,

*Corresponding author: Magda AAkl, Chemistry Department, Faculty of Science, Mansorua University, Egypt, Tel: 0020502217833; E-mail: magdaakl@yahoo.com

Received August 17, 2015; Accepted September 05, 2015; Published December 01,2015

Citation: AkI MA, Abou-Elanwar AM (2015) Adsorption Studies of Cd (II) from Water by Acid Modified Multiwalled Carbon Nanotubes. J Nanomed Nanotechno 6: 327. doi:10.4172/2157-7439.1000327

Copyright: (c) 2015 Akl MA, et al. This is an open-access article distributed unde the terms of the Creative Commons Attribution License, which permits unrestricted use, distribution, and reproduction in any medium, provided the original author and source are credited. 
HANNA, and Portugal). The adsorbents were weighed using analytical balance. Water bath shaker was used for adsorption experiments. An Analyst 300 Perkin Elmer (FAAS) was used for the quantitative determination. The concentration of $\mathrm{Cd}(\mathrm{II})$ was detected using flame atomic absorption spectrometer.

\section{Modification of carbon nanotubes (CNTs) by nitric acid}

65 A $10 \mathrm{~g}$ of multi-walled carbon nanotubes (Sigma-Aldrich) was refluxed in $100 \mathrm{ml}$ nitric acid for $4 \mathrm{~h}$. Subsequently, the carbon was filtered off using $0.45 \mu \mathrm{m}$ Millipore filter papers and Buchner funnel. The filtrate was washed with water until the $\mathrm{pH}$ reached a value of 5.5. The carbon was dried overnight under ambient conditions and then for $24 \mathrm{~h}$ at $110^{\circ} \mathrm{C}$. This modified carbon nanotubes was designated MCNT$\mathrm{HNO}_{3}$.

\section{Adsorbent characterization}

The surface functional groups present on the carbons were investigated using a Fourier transform infrared spectroscopy (FT-IR) by spectrophotometer (Jasco, Model 6100- Japan) using KBr pressed disc- method. The Boehm titration method was applied to determine the surface functional groups containing oxygen [23-25]. The surface $\mathrm{pH}$ and $\mathrm{pH} \mathrm{P}_{\mathrm{ZC}}$ point of zero charge were evaluated [26,27]. The BET surface areas (SBET) of the carbons were measured by $\mathrm{N}_{2}$ adsorption at $77 \mathrm{~K}$ using Surface Area and Pore Size Analyzer (QUANTACHROME - NOVA 2000 Series) [28]. Analysis of the isotherms was carried out by applying the as method to obtain: $S^{\alpha}, S_{n}^{\alpha}$ (total and non-microporous surface areas) and the micropore volume $V_{\mathrm{m}}^{\alpha}$ [29], also the total pore volume $\left(\mathrm{V}_{\mathrm{T}}\right)$ and the average pore radius $(\bar{r})(\mathrm{nm})$ were estimated [27]. The surface micrographs of the carbons were examined using a scanning electron microscope JSE-T20 (JEOL, Japan) at $40 \mathrm{~kW}$ and high resolution transmission electron microscope (JOEL JEM2010 HR-TEM) at $200 \mathrm{kV}$.

\section{Adsorption experiments}

The adsorption performances of Cd(II) onto CNT and MCNTHNO3 were examined by batch adsorption experiments on water-bath shaker at $150 \mathrm{rpm}$ using (100-1000) $\mathrm{mL}$ conical flasks. The effect of $\mathrm{pH}$ on Cd(II) removal was studied by agitating $0.04 \mathrm{~g}$ sorbent with $25 \mathrm{ml}$ of $150 \mathrm{ppm} \mathrm{Cd}$ (II) solutions with $\mathrm{pH}$ rang (2-8) for $24 \mathrm{~h}$ at $303.15 \mathrm{~K}$. The $\mathrm{pH}$ of metal ion solution was adjusted by using $0.1 \mathrm{M} \mathrm{HCl}$ or $0.1 \mathrm{M}$ $\mathrm{NaOH}$. The isotherm study was performed by shaking $0.04 \mathrm{~g}$ of sorbents with $25 \mathrm{ml}$ adsorbates solutions of various $\mathrm{Cd}(\mathrm{II})$ concentrations $(10-300 \mathrm{ppm})$ for $24 \mathrm{~h}$ at $303.15 \mathrm{~K}$. In the kinetics study, $0.25 \mathrm{~g}$ of the carbons Iwere added to $500 \mathrm{ml}$ of $20 \mathrm{ppm} \mathrm{Cd}(\mathrm{II})$ solutions and shaken at different time intervals $(15 \mathrm{~min}-24 \mathrm{~h})$ then samples were taken from the solution by fast filtration. The effect of adsorbent dose was investigated by equilibrating $25 \mathrm{ml}$ of $100 \mathrm{ppm}$ metal solutions and different doses of adsorbents $(0.05 \mathrm{~g}-0.4 \mathrm{~g})$. The influence of the temperature was tested by equilibrating $0.04 \mathrm{~g}$ of samples with $25 \mathrm{ml}$ aqueous solution containing different concentration of metal (10-300 ppm) at $303.15,318.15$ and 333.15 .

The adsorption capacities of adsorbents were calculated using the following expression:

$$
q_{t}=\frac{\left(C_{0}-C_{t}\right) \cdot V}{m}
$$

Where, $\mathrm{q}_{\mathrm{t}}$ is the adsorption capacity of the adsorbent at time $\mathrm{t}(\mathrm{mg}$ adsorbate/g adsorbent); $\mathrm{C}_{0}$ is the initial concentration of metal $(\mathrm{mg} / \mathrm{L})$; $\mathrm{C}_{\mathrm{t}}$ is the residual concentration of metal after adsorption had taken place over a period of time $\mathrm{t}(\mathrm{mg} / \mathrm{L}) ; \mathrm{V}$ is volume of metal solution in shake flask (L) and $\mathrm{m}$ is mass of adsorbent ( $\mathrm{g}$ ). The removal percentage of metals ions from aqueous solution is computed as follows:

$$
\text { Removal \% }=\frac{\left(C_{0}-C_{t}\right) \cdot 100}{C_{0}}
$$

In order to investigate the desorption capacity of $\mathrm{Cd}$ (II) from adsorbents, $0.04 \mathrm{~g}$ of the carbons were introduced to $50 \mathrm{ml}$ solution whose initial concentration is) $50 \mathrm{ppm} \mathrm{Cd(II)} \mathrm{at} \mathrm{pH}=4.5)$. After equilibrium, the Cd (II) concentration of the solution was measured, and then the solution was filtrated using a membrane to recover the carbon sample. These samples were dried at $80^{\circ} \mathrm{C}$ and dispersed into $50 \mathrm{ml}$ distilled water. The $\mathrm{pH}$ values of the solution were adjusted from 1.5 to 5.5 using $\mathrm{HCl}$. After equilibrium, Cd (II) concentration were measured and the desorption results were then obtained. These adsorption/desorption processes were repeated for three times, to further ascertain the desorption capability of adsorbents. The desorption \% of metal ions from adsorbents was calculated as follow:

$$
\text { Desorption } \%=\frac{\text { Amount released to solution }(\mathrm{ppm})}{\text { Total Adsorbed }(\mathrm{ppm})} \times 100 \%
$$

\section{Results and Discussion}

\section{Characterization of the adsorbents}

FT IR: Figure 1 showed the FTIR spectra of pristine carbon nanotubes (CNT) and acidified $\mathrm{MCNT}-\mathrm{HNO}_{3}$. The both nanotubes samples show wide band at about $\left(3250-3425 \mathrm{~cm}^{-1}\right)$ due to $\mathrm{O}-\mathrm{H}$ stretching mode of hexagonal group and adsorbed water, shoulders observed at $\left(2850-2950 \mathrm{~cm}^{-1}\right)$ due to aliphatic $(\mathrm{C}-\mathrm{H})$, peaks at $(1620$ $\left.1630 \mathrm{~cm}^{-1}\right)$ due to $(\mathrm{C}=\mathrm{C})[29,30]$. For MCNT-HNO ${ }_{3}$, the shoulder appeared at $\left(1675 \mathrm{~cm}^{-1}\right)$ may be assigned to $(\mathrm{C}=\mathrm{O})$ of carbonyl groups indicating successful surface functional modification [31-33].

Surface acidity and Boehm titration: Table 1 summarizes the results of Boehm titration for $\mathrm{MCNT}-\mathrm{HNO}_{3}$. The total number of the surface basic sites (carbonyl and chromene) was smaller than the total number of the acidic surface sites (carboxylic, lactonic and Phenolic). This is in agreement with the surface $\mathrm{pH}$ and point of zero charge $\mathrm{pH}_{\mathrm{PZC}}$ which are also acidic.

Surface area measurements: Figure 2 illustrates the nitrogen adsorption-desorption isotherms at $77 \mathrm{~K}$ on CNT and MCNT-HNO . Table 2 gives the porous properties of the pristine CNT and MCNT$\mathrm{HNO}_{3}$ obtained from the analysis of $\mathrm{N}_{2}$ adsorption isotherms [34]. It is observed that surface areas $\left(\mathrm{S}_{\mathrm{BET}}, \mathrm{S}^{\alpha}, \mathrm{Sn}^{\alpha}\right)$ and pore volumes $\left(\mathrm{V}_{\mathrm{T}}, \mathrm{V}_{\mathrm{n}}^{\alpha}\right)$ of the CNT increased after oxidation with increasing Average pore radius

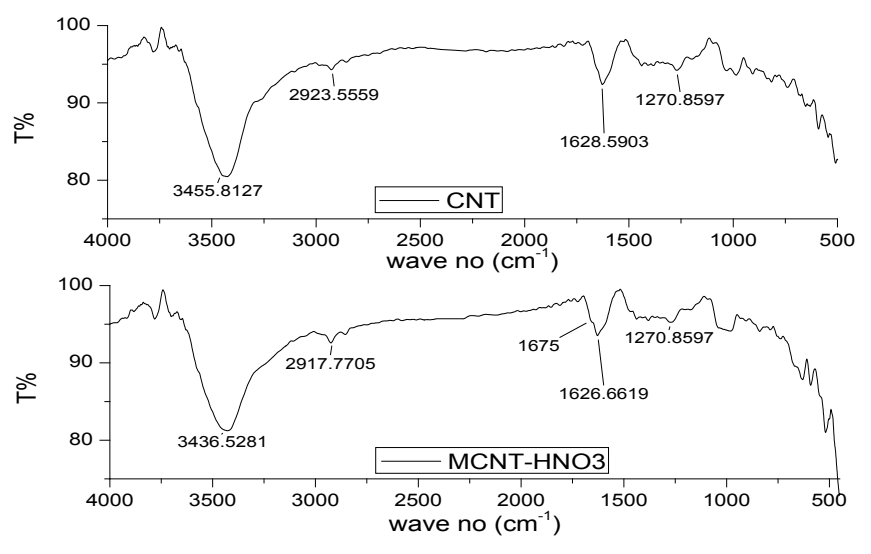

Figure 1: FTIR spectra of CNT and MCNT- $\mathrm{HNO}_{3}$. 
Citation: AkI MA, Abou-Elanwar AM (2015) Adsorption Studies of Cd (II) from Water by Acid Modified Multiwalled Carbon Nanotubes. J Nanomed Nanotechnol 6: 327. doi:10.4172/2157-7439.1000327

Page 3 of 9

\begin{tabular}{|l|c|c|c|c|c|c|}
\hline $\begin{array}{l}\text { Type of } \\
\text { carbon }\end{array}$ & $\begin{array}{c}\text { Carboxylic } \\
\text { (mmol/g) }\end{array}$ & $\begin{array}{c}\text { Lactonic } \\
(\mathbf{m m o l} / \mathbf{g})\end{array}$ & $\begin{array}{c}\text { Phenolic } \\
(\mathbf{m m o l} / \mathbf{g})\end{array}$ & $\begin{array}{c}\text { Total Acidic groups } \\
\text { (mmol/g) }\end{array}$ & $\begin{array}{c}\text { Basic groups } \\
\text { (mmol/g) }\end{array}$ & $\begin{array}{c}\text { Surface } \mathbf{p H} \\
\text { Point of zero charge }\end{array}$ \\
\hline CNT & - & - & & - & - \\
\hline MCNT-HNO & 0.078 & 0.0225 & 0.0456 & 0.1461 & 6.15 \\
\hline
\end{tabular}

Table 1: Boehm titration, Surface $\mathrm{pH}$ and point of zero charge for CNT and $\mathrm{MCNT}_{\mathrm{HNO}}$.

\begin{tabular}{|c|c|c|c|c|c|c|c|c|}
\hline & $\mathrm{S}_{\mathrm{BET}}\left(\mathrm{m}^{2} / \mathrm{g}\right)$ & $\mathbf{S}^{\alpha}\left(\mathrm{m}^{2} / \mathrm{g}\right)$ & $\left(\mathrm{m}^{2} / \mathbf{g}\right) S_{n}^{\alpha}$ & $\left(\mathrm{m}^{2} / \mathrm{g}\right) S_{n}^{\alpha}$ & $(\mathrm{ml} / \mathrm{g}) \mathrm{V}_{\mathrm{T}}$ & $(\mathbf{m l} / \mathbf{g}) V_{m}^{\alpha}$ & $(\mathbf{m l} / \mathbf{g}) V_{n}^{\alpha}$ & $(\mathrm{nm}) \bar{r}$ \\
\hline CNT & 198.18 & 220.16 & 99.34 & 120.82 & 0.325 & 0.06 & 0.26 & 3.28 \\
\hline MCNT-HNO & 288.45 & 285.12 & 1.25 & 283.87 & 0.899 & 0.0032 & 0.8954 & 6.23 \\
\hline
\end{tabular}

Table 2: $\mathrm{N}_{2}$ adsorption and surface area data of CNT and MCNT-HNO .
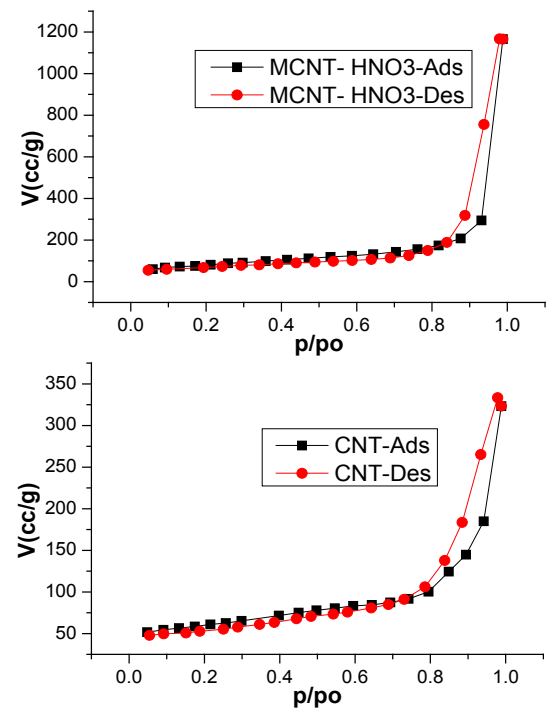

Figure 2: Nitrogen adsorption- desorption isotherms at 77K for CNT and $\mathrm{MCNT}-\mathrm{HNO}_{3}$.

$(\bar{r})$. This may be attributed to opening up the carbon nanotubes ends [35] and generation of defects on the sidewall of nanotubes by functionalization $[36,37]$, hence the access into the cavity of the nanotubes can be achieved. CNTs tend to form long bundles stabilized by numerous $\Pi-\Pi$ interaction between the tubes. Also, presence of functional groups on the surface of nanotubes generates repulsion force which leads to debundeling of nanotubes and so leads to increase of surface area.

SEM and TEM: The morphology of pristine multi-walled carbon nanotubes (CNT) and oxidized form $\left(\mathrm{MCNT}-\mathrm{HNO}_{3}\right)$ was investigated by scanning electron microscope at magnification power $12000 \mathrm{X}$ as shown in Figures $3 \mathrm{a}$ and $3 \mathrm{~b}$. From the SEM observation, the agglomeration of carbon nanotubes bundles were observed but without distinct difference in morphology between CNT and MCNT$\mathrm{HNO}_{3}$. The transmission electron microscopy (TEM) was carried out to characterize the structure of $\mathrm{CNT}$ and $\mathrm{MCNT}-\mathrm{HNO}_{3}$. Figures $3 \mathrm{c}$ and $3 \mathrm{~d}$ showed that the average diameter of nanotubes (CNT and MCNT$\mathrm{HNO}_{3}$ ) was about 5-6 nm with length above $3 \mu \mathrm{m}$ and displayed that the nanotubes of $\mathrm{MCNT}-\mathrm{HNO}_{3}$ become shorter than $\mathrm{CNT}$ which may be attributed to the destruction of the nanotubes by nitric acid. It is also observed that the impurities in the acidic-treated $\mathrm{MCNT}-\mathrm{HNO}_{3}$ are obviously decreased than CNT.

\section{Adsorption and desorption studies}

Effect of $\mathbf{p H}$ on the adsorption of $\mathrm{Cd}(\mathrm{II})$ : The solution $\mathrm{pH}$ is
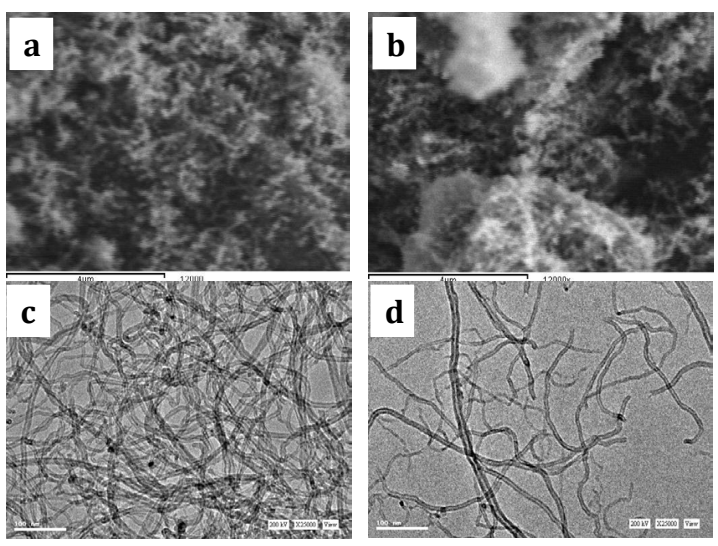

Figure 3: SEM micrograph (a) for CNT and (b) for $\mathrm{MCNT}^{-} \mathrm{HNO}_{3}$ and TEM micrograph (c) for CNT and (d) for MCNT $-\mathrm{HNO}_{3}$.

identified as an important parameter which governs the adsorption of ion at the solid-water interfaces. The $\mathrm{pH}$ accepted its vital role because it affects the solubility of the metal ions, concentration of the counter ions on the functional groups of adsorbent and the degree of ionization of the adsorbate during the reaction.

When $\mathrm{pH}$ of the solution is lower than $\mathrm{pH}_{\mathrm{PZC}}$ (Point of Zero Charge), the positive charge on the surface provides electrostatic repulsions that are unfavorable for adsorbing cationic species and vice versa thus the increase of $\mathrm{pH}$ leads to increase negative charge on the carbon surface, thus, the adsorption of cations should increase.

The removal of cadmium by two types of adsorbents (modified and non-modified CNTs) has been studied within $\mathrm{pH}$ range from 2 to 6.5 . This $\mathrm{pH}$ range was chosen to avoid precipitation of $\mathrm{Cd}^{2+}$ as $\mathrm{Cd}(\mathrm{OH})_{2}$ due to exceeding in $\mathrm{pH}$ and hence the removal of the metal could be attributed to the adsorption process only. Figure 4 shows the effect of $\mathrm{pH}$ on the adsorption of $\mathrm{Cd}^{2+}$ on raw carbon nanotubes (CNT) and modified carbon nanotubes $\left(\mathrm{MCNT}-\mathrm{HNO}_{3}\right)$. The found data indicate that the functional groups introduced by oxidation improve the ionexchange capabilities of carbon nanotubes and make $\mathrm{Cd}^{2+}$ adsorption capacity increase correspondingly. At lower $\mathrm{pH}$, the adsorption quantity of $\mathrm{Cd}(\mathrm{II})$ was very low which is attributed to the electrical repulsion between $\mathrm{Cd}(\mathrm{II})$ ions and positively charged function groups on the carbon surface would be responsible for the low Cd(II) adsorption. With increasing solution $\mathrm{pH}$, the carbon surface became more negatively charged due to the dissociation of the function groups, which could enhance the electrostatic interactions of $\mathrm{Cd}^{2+}$ ions with negative function groups and facilitate the $\mathrm{Cd}$ ion adsorption. It can be observed that, the removal of cadmium from water by using modified 


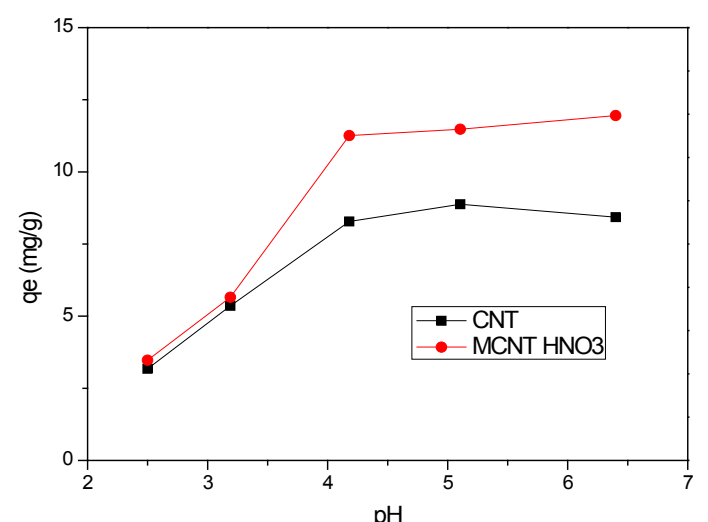

Figure 4: Effect of $\mathrm{pH}$ on adsorption of $\mathrm{Cd}$ (II) on $\mathrm{CNT}$ and $\mathrm{MCNT}-\mathrm{HNO}_{3}$.

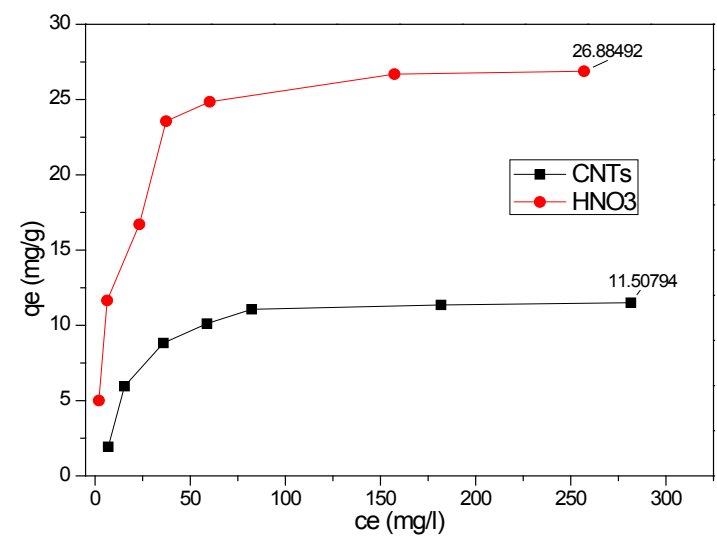

Figure 5: Adsorption isotherm of $\mathrm{Cd}(\mathrm{II})$ on $\mathrm{CNT}$ and $\mathrm{MCNT}-\mathrm{HNO}_{3}$.

carbon nanotubes remarkable higher than the raw carbon nanotubes due to the ionization step by the functional group on the surface of CNTs. At pH 5.6 it was possible to carry out the adsorption of $\mathrm{Cd}(\mathrm{II})$ at higher concentration.

Effect of initial concentrations: Cadmium (II) adsorption capacities of the raw and oxidized CNT are given as a function of the equilibrium concentration of $\mathrm{Cd}(\mathrm{II})$ ions in Figure 5. It can be seen that the adsorption of $\mathrm{Cd}(\mathrm{II})$ on $\mathrm{CNT}$ and $\mathrm{MCNT}-\mathrm{HNO}_{3}$ increased with the initial or equilibrium $\mathrm{Cd}(\mathrm{II})$ concentrations, due to the increase in the driving force of the concentration gradient as a result of increasing the metal ion initial concentration $[38,39]$. It is clear that the oxidized form MCNT- $-\mathrm{HNO}_{3}$ appeared to be more effective under a higher aqueous Cd (II) concentration as compared with raw CNT (CNT:11.5 mg/g , $\mathrm{MCNT}^{-} \mathrm{HNO}_{3}: 26.88 \mathrm{mg} / \mathrm{g}$ ). The adsorbed amounts at equilibrium by $\mathrm{MCNT}-\mathrm{HNO}_{3}$ were estimated to be almost 2.34 times as much as the capacity by CNT Apparently, this indicates that the functional groups introduced by oxidation improve the ion-exchange capabilities of the CNTs and thus make Cd(II) adsorption capacities increase correspondingly.

Effect of contact time: The effect of contact time was studied for the carbons by varying the equilibrium time from 5 minutes to 24 hours at pH 5.6. From Figure 6 it can be seen that the amount of $\mathrm{Cd}^{2+}$ adsorbed onto both raw carbon nanotubes (CNT) and modified $\mathrm{CNT}\left(\mathrm{MCNT}-\mathrm{HNO}_{3}\right)$ increased rapidly during the beginning 10 minutes. Subsequently, the adsorption rate rises gradually and reaches equilibrium after $5 \mathrm{~h}$ for $\mathrm{Cd}^{2+}$ adsorption by using (CNT) and (MCNT$\mathrm{HNO}_{3}$ ). The short time required to reach equilibrium suggests that the (M-CNTs) have very high adsorption efficiency and have a great potential in $\mathrm{Cd}^{2+}$ adsorbent application.

Effect of adsorbent dosage: The dose of carbon nanotubes in the water is one of the major parameters, which affect the adsorption capacity. The batch adsorption experiments were carried out by using various amounts of M-CNTs at $\mathrm{pH}$ 5.6. The data depicted in Figure 7 showed that changing the adsorbent concentration from $0.05 \mathrm{~g}$ to 0.4 $\mathrm{g} / 25 \mathrm{ml}$ increased the removal \% of Cd (II) ions from $16.67 \%$ to $56.67 \%$ for $\mathrm{CNT}$ and from $66.83 \%$ to $100 \%$ for both $\mathrm{MCNT}-\mathrm{HNO}_{3}$ from solution containing $100 \mathrm{ppm}$ of $\mathrm{Cd}$ (II). This is expected because the higher the dose of adsorbents in the solution, the greater the availability of exchangeable sites for ions. This suggests that after a certain dose of adsorbent, the maximum adsorption sets in and hence the amount of ions bound to the adsorbent and the amount of free ions remains constant even with further addition of the dose of adsorbent. It was also found that the amount adsorbed per unit mass decreases by increasing the adsorbent dose. The decrease in adsorption density with increase in the adsorbent dose is mainly due to the unsaturation of adsorption sites through the adsorption process $[40,41]$. The particle interaction, such as aggregation, resulting from high adsorbent dose may also a reason for this behavior. Such aggregation would lead to decrease in

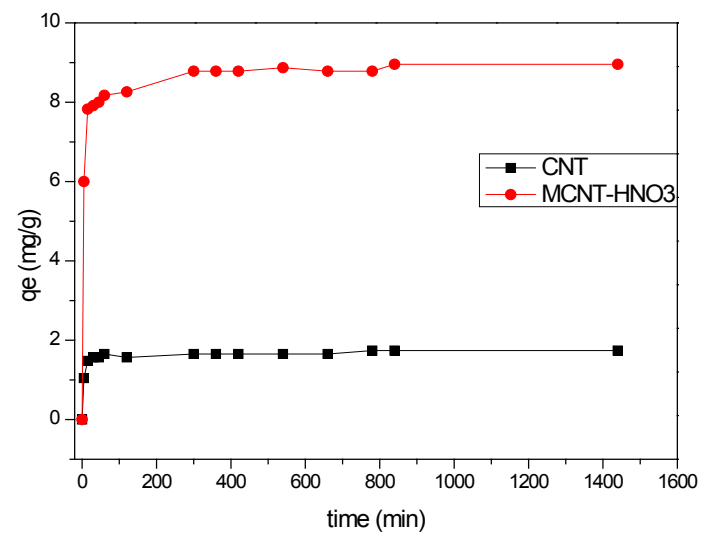

Figure 6: Effect of contact time on adsorption of $\mathrm{Cd}(\mathrm{II})$ on CNT and $\mathrm{MCNT}^{-} \mathrm{HNO}_{3}$.

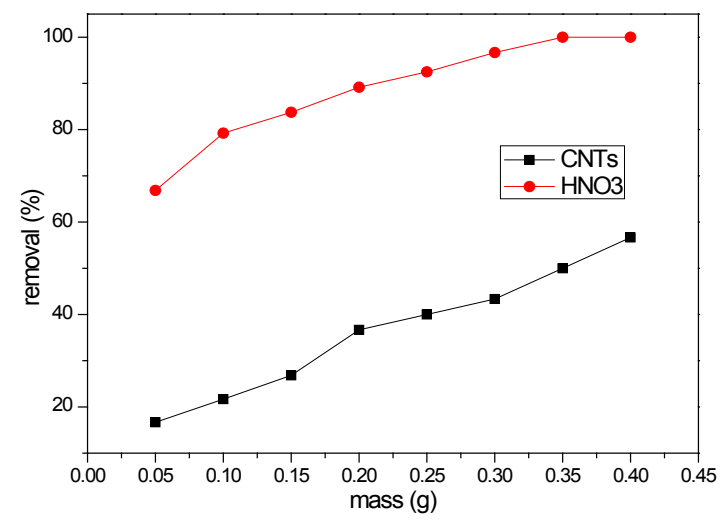

Figure 7: The effect of mass on adsorption of $\mathrm{Cd}(\mathrm{II})$ on CNT and $\mathrm{MCNT}-\mathrm{HNO}_{3}$. 
total surface area of the adsorbent and an increase in diffusional path length [41].

Equilibrium adsorption studies: The equilibrium adsorption isotherms are of fundamental importance in the study and design of adsorption systems. The adsorption of aqueous species on solid surface may be described by various isotherms including Langmuir, Freundlich, Sips and Redlich-Peterson isotherm equations [42]. Langmuir and Freundlich isotherms relate the coverage or adsorption of molecules on a solid surface to concentration of a medium above the solid surface at a fixed temperature. In this study, the regression analysis of experimental data has been carried out using both the Langmuir and Freundlich isotherm models. The linear form of Langmuir isotherm equation is given as:

$$
\frac{1}{\mathrm{q}_{\mathrm{e}}}=\frac{1}{\mathrm{bq}_{\mathrm{m}}}+\frac{1}{\mathrm{c}_{\mathrm{e}}}
$$

where $b$ is Langmuir equilibrium constant $(1 / \mathrm{mg})$, and $\mathrm{q}_{\mathrm{m}}(\mathrm{mg} / \mathrm{g})$ is the monolayer adsorption capacity. Both are determined from a plot $\mathrm{Ce} / \mathrm{qe}$ versus Ce (Figure 8a). Langmuir isotherm is frequently evaluated by a separation factor, $R_{L}$, which is defined as follows:

$$
\mathrm{R}_{\mathrm{L}}=\frac{1}{1+\mathrm{bC}_{0}}
$$

where $\mathrm{C}_{0}$ in this case is the highest initial solute concentration. The value of separation factor indicates the type of the isotherm and the nature of the adsorption process. Considering the $\mathrm{R}_{\mathrm{L}}$ value, adsorption can be unfavorable $\left(\mathrm{R}_{\mathrm{L}}>1\right)$, linear $\left(\mathrm{R}_{\mathrm{L}}=1\right)$, favorable $\left(0<\mathrm{R}_{\mathrm{L}}<1\right)$ or irreversible $\left(R_{L}=0\right)$ [43]. In our case, all the $R_{L}$ value was found to be $\left(0<R_{L}<1\right)$ which confirmed that all adsorbents show favorable adsorption for $\mathrm{Cd}(\mathrm{II})$ ions. The $\mathrm{R}_{\mathrm{L}}$ values indicate that favorability of the adsorption on MCNT- $-\mathrm{HNO}_{3}\left(\mathrm{R}_{\mathrm{L}}=0.281\right)$ is greater than $\mathrm{CNT}\left(\mathrm{R}_{\mathrm{L}}=0.061\right)$. Freundlich isotherm is purely empirical and it best describes the adsorption on heterogeneous surfaces [44]. Freundlich isotherm equation is shown below in its linear form:

\begin{tabular}{|l|c|c|c|c|c|c|c|}
\hline \multirow{2}{*}{ Adsorbents } & \multicolumn{4}{|c|}{ Langmuir constants } & \multicolumn{3}{c|}{ Freundlich constants } \\
\cline { 2 - 8 } & $\mathbf{q}_{\mathbf{m}}(\mathbf{m g} / \mathbf{g})$ & $\mathbf{b}(\mathbf{L} / \mathbf{m g})$ & $\mathbf{R}^{\mathbf{2}}$ & $\mathbf{R}_{\mathbf{L}}$ & $\mathbf{K}_{\mathbf{F}}$ & $\mathbf{1 / n}$ & $\mathbf{R}^{\mathbf{2}}$ \\
\hline CNT & 11.5 & 0.051 & 0.99 & 0.061 & 3.83 & 0.2141 & 0.759 \\
\hline MCNT-HNO & 26.88 & 0.0085 & 0.999 & 0.281 & 8.5 & 0.23 & 0.816 \\
\hline
\end{tabular}

Table 3: Langmuir and Freundlich isotherm constants for Cd(II) adsorption CNT and $\mathrm{MCNT}-\mathrm{HNO}_{3}$.

$$
\mathrm{q}_{\mathrm{e}}=\mathrm{K}_{\mathrm{f}} \mathrm{C}_{\mathrm{e}}^{\frac{1}{\mathrm{n}}}
$$

where $K_{F}(l / g)$ is Freundlich constant and $n$ is Freundlich exponent. These parameters are determined from a plot $\log \mathrm{q}_{e}$ versus $\log \mathrm{C}_{\mathrm{e}}$ (Figure $8 \mathrm{~b}$ ). The isotherm parameters for the adsorption of $\mathrm{Cd}(\mathrm{II})$ ions onto carbons are given in Table 3. Langmuir adsorption model provides the best fit with experimentally obtained data for both CNT $\left(\mathrm{r}^{2}>0.990\right)$ and $\mathrm{MCNT}-\mathrm{HNO}_{3}\left(\mathrm{r}^{2}>0.998\right)$. The magnitude of $1 / \mathrm{n}$ quantifies the favorability of adsorption and the degree of heterogeneity of the CNTs surface. If $1 / \mathrm{n}$ is less than 1 , suggesting favorable adsorption, then the adsorption capacity increases and new adsorption sites form. The values of $1 / \mathrm{n}$ confirmed the favorability of adsorption on MCNT$\mathrm{HNO}_{3}$ and CNT.

Adsorption kinetics: In order to clarify the adsorption kinetics process of $\mathrm{Cd}(\mathrm{II})$ on carbons two kinetic models, pseudo-first-order and pseudo-second-order were applied to the experimental data.

\section{Pseudo first-order equation}

The pseudo-first-order kinetic model is frequently used in kinetic studies [45]. It is expressed by the following equation:

$$
\log \left(\mathrm{q}_{\mathrm{e}}-\mathrm{q}_{\mathrm{t}}\right)=\log \mathrm{q}_{\mathrm{e}}-\frac{\mathrm{k}_{1}}{2.303} \mathrm{t}
$$

Where $\mathrm{q}_{\mathrm{e}}$ and $\mathrm{q}_{\mathrm{t}}(\mathrm{mg} / \mathrm{g})$ are the amounts of $\mathrm{Cd}(\mathrm{II})$ adsorbed at equilibrium and at time $t$, respectively and $k$, is the equilibrium constant $\left(\mathrm{min}^{-1}\right)$ which were obtained from the slopes of the linear plots of $\ln \left(\mathrm{q}_{\mathrm{e}}-\mathrm{q}_{\mathrm{t}}\right)$ versus $\mathrm{t}$ (Figure 9a).

\section{Pseudo second-order equation}

The pseudo-second-order kinetic model may be expressed by the equation:

$$
\frac{\mathrm{t}}{\mathrm{q}_{\mathrm{t}}}=\frac{1}{\mathrm{k}_{2} \mathrm{q}_{\mathrm{e}}^{2}}+\frac{1}{\mathrm{q}_{\mathrm{e}}} \mathrm{t}
$$

Where $\mathrm{k}_{2}(\mathrm{~g} / \mathrm{mg} \mathrm{min})$ is the equilibrium rate constant for the pseudo second-order adsorption and $\mathrm{q}_{\mathrm{e}}$ can be obtained from the plot of $\mathrm{t} / \mathrm{q}_{\mathrm{t}}$ against $\mathrm{t}$ (Figure $9 \mathrm{~b}$ ) [46].

A comparison of the results with the correlation coefficients for the first-order kinetic and second-order kinetic models is shown in Table 4. The pseudo first-order kinetic equation was not applicable because $\mathrm{R}^{2}$ is small comparing to $\mathrm{R}^{2}$ of pseudo second-order equation for both
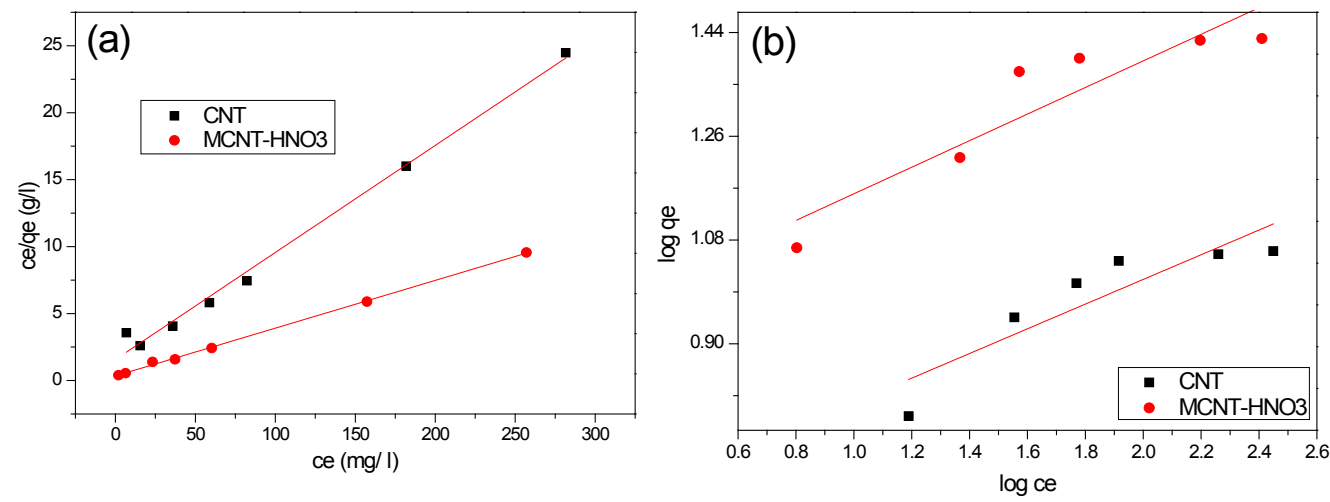

Figure 8: Adsorption isotherm model ofPb(II) on CNT and $\mathrm{MCNT}^{-\mathrm{HNO}_{3}}$ (a) Langmuir and (b) Freundlich. 

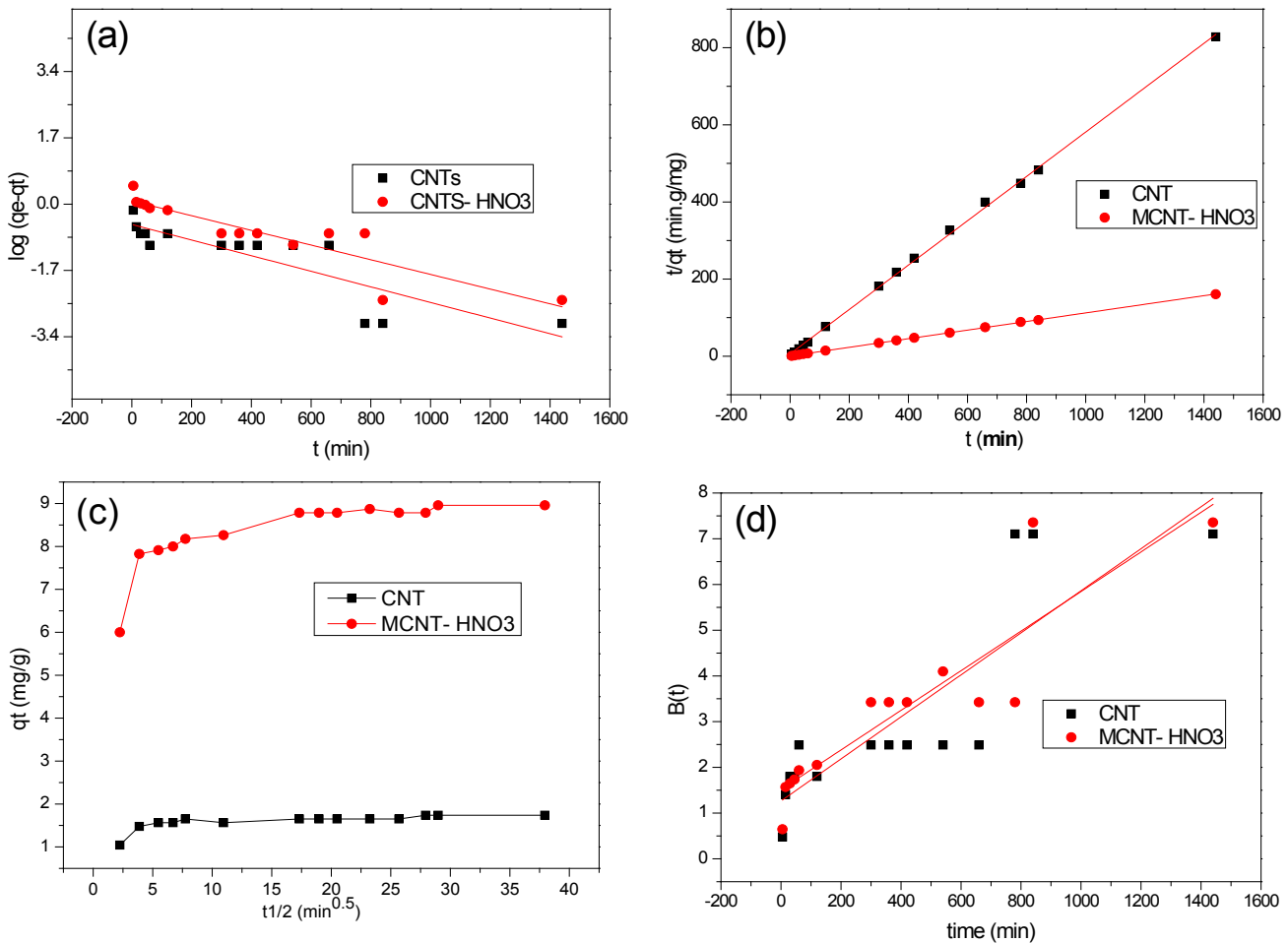

Figure 9: Kinetic models for adsorption of Cd(II) (a) Pseudo-first order, (b) Pseudo-second order, (c) Intra particle diffusion and (d) Boyd plot.

sorbents ( $\mathrm{CNT}$ and $\mathrm{MCNT}-\mathrm{HNO}_{3}$ ). Hence the pseudo second order model was considered the best fit model for experimental kinetic data which also gave $\mathrm{q}_{e}$ values agree very well with the experimental data for both adsorbents (CNT and $\left.\mathrm{MCNT}-\mathrm{HNO}_{3}\right)$.

\section{Intraparticle diffusion equation}

Because Equations 9 and 10 cannot identify the diffusion mechanisms, thus the intraparticle diffusion model was also tested [4749]. Intraparticle diffusion model is defined by the following equation:

$$
\mathrm{q}_{\mathrm{t}}=\mathrm{k}_{\text {int }} \mathrm{t}^{0.5}+\mathrm{C}
$$

where $\mathrm{k}_{\mathrm{int}}(\mathrm{g} / \mathrm{mg} \min 1 / 2)$ is the constant of the adsorption, $\mathrm{C}$ is the intercept and can be determined from a plot $q_{t}$ versus $t^{1 / 2}$ (Figure 9c) [50]. Such plots may present a multi-linearity $[51,52]$, indicating that two or more steps take place. The first, sharper portion is the external surface adsorption or instantaneous adsorption stage. The second portion is the gradual adsorption stage, where intraparticle diffusion is rate-controlled and from it $\mathrm{K}_{\mathrm{int}}$ is obtained. The third portion is the final equilibrium stage where intraparticle diffusion starts to slow down due to extremely low adsorbate concentrations in the solution.

\section{Boyd equation}

The kinetic data were further analyzed using the kinetic expression given by Boyd et al. [53] to check whether adsorption proceeds via an external diffusion or intraparticle diffusion mechanism, which is expressed as follows:

$$
F(t)=1-\frac{6}{\pi^{2}} \sum_{n=1}^{\infty} \frac{1}{n^{2}} \exp \left(-n^{2} B t\right)
$$

Where $\mathrm{F}$ is the fractional of equilibrium at different times $(\mathrm{t})$, and $\mathrm{B}$

\begin{tabular}{|c|c|c|c|}
\hline \multirow{5}{*}{ First-order kinetic equation } & & CNT & $\mathrm{M}$ CNT $-\mathrm{HNO}_{3}$ \\
\hline & $q e, \exp (\mathrm{mg} / \mathrm{g})$ & 1.74 & 8.96 \\
\hline & $\mathrm{q}_{1}(\mathrm{mg} / \mathrm{g})$ & 0.3 & 1.2 \\
\hline & $\mathrm{k}_{1}\left(\mathrm{~min}^{-1}\right) \times 10^{-3}$ & 4.61 & 4.33 \\
\hline & $R_{1}^{2}$ & 0.7172 & 0.8033 \\
\hline \multirow{4}{*}{$\begin{array}{l}\text { Second-order kinetic } \\
\text { equation }\end{array}$} & $\mathrm{q}_{2}(\mathrm{mg} / \mathrm{g})$ & 1.7385 & 8.9598 \\
\hline & $\mathrm{k}_{2}$ & 0.0541 & 0.018 \\
\hline & {$[\mathrm{g} /(\mathrm{mg} \mathrm{min})] \times 10^{-3}$} & & \\
\hline & $R_{2}^{2}$ & 0.99918 & 0.99987 \\
\hline \multirow{4}{*}{$\begin{array}{c}\text { Intraparticle } \\
\text { diffusion equation }\end{array}$} & $\mathrm{k}_{\mathrm{int}}$ & 0.00645 & 0.03655 \\
\hline & {$[\mathrm{mg} /(\mathrm{g} \min 1 / 2)]$} & & \\
\hline & $\mathrm{C}$ & 1.52197 & 7.86686 \\
\hline & $R_{\mathrm{int}}^{2}$ & 0.74589 & 0.82195 \\
\hline \multirow{2}{*}{ Boyd equation } & Intercept & 1.265 & 0.448 \\
\hline & $\mathrm{R}^{2}$ & 0.71747 & 0.8039 \\
\hline
\end{tabular}
$(\mathrm{t})$ is mathematical function of $\mathrm{F}, \mathrm{n}$ is an integer that defines the infinite
Table 4: Kinetic parameters for the adsorption of for $\mathrm{Cd}(\mathrm{II})$ adsorption CNT and MCNT- $-\mathrm{NNO}_{3}$.

series solution and $\mathrm{F}$ is the fractional attainment of equilibrium at time $t$ and is obtained by the expression:

$$
F=\frac{q_{t}}{q_{e}}
$$

where $q_{t}$ and $q_{e}$ is the amount of metal ion adsorbed at time (t) and equilibrium respectively Reichenberg [54] managed to obtain the following approximations:

For $\mathrm{F}$ values $>0.85$;

$$
B(t)=-0.4977-\ln (1-F)
$$


And for $\mathrm{f}$ values $<0.85$;

$$
B(t)=\left(\sqrt{\pi}-\sqrt{\pi-\left(\frac{\pi^{2} F(t)}{3}\right)}\right)^{2}
$$

None of the intraparticle diffusion plots passed through the origin (Figure 9c), which showed that the intraparticle diffusion was part of the adsorption but was not the only rate-controlling step and indicates the effect of film diffusion (boundary layer diffusion) on adsorption of cadmium. Also Boyd plots (Figure 9d) didn't pass through the origin indicating that film diffusion is the rate-limiting adsorption process for $\mathrm{Cd}(\mathrm{II})$ adsorption on both CNT and $\mathrm{MCNT}-\mathrm{HNO}_{3}$.

Effect of temperature and Thermodynamic studies: The change in standard free energy of adsorption $\left(\ddot{\mathrm{A}} \mathrm{G}^{\circ}\right)$ was calculated from the variations of the Langmuir constants, $b(1 / \mathrm{mol})$ with change in temperature using the following equation:

$$
\ddot{A} G^{\circ}=-R T \operatorname{lnb}
$$

Where $\mathrm{R}$ is gas constant $(8.314 \mathrm{~J} / \mathrm{mol} / \mathrm{K})$, $\mathrm{T}$ is temperature in $\mathrm{K}$. Standard enthalpy $\left(\ddot{\mathrm{H}} \mathrm{H}^{\circ}\right.$ ) and entropy ( $\left.\mathrm{A} \mathrm{S}^{\circ}\right)$ of adsorption could be estimated from Van't Hoff equation:

$$
1 n b=\frac{-\Delta H^{\circ}}{R T}+\frac{\Delta S^{\circ}}{R}
$$

The plot of $\ln \mathrm{b}$ vs. $1 / \mathrm{T}$ was found to be linear (Figure 10) and $\Delta \mathrm{H}^{\circ}$ was computed from the slope. $\Delta S^{\circ}$ was obtained from the intercept. The negative values of $\mathrm{AG}^{\circ}$ (Table 5) for all adsorbents indicate the process to be feasible and spontaneous. The amount adsorbed at equilibrium must increase with increasing temperature, because $\mathrm{AG}^{\circ}$ decreases with increasing temperature of the solution. This explains why the negative of $\mathrm{AG}^{\circ}$ values increase with increasing temperature. The positive value of $\Delta \mathrm{H}^{\circ}$ for all carbons reflects the endothermic nature of the

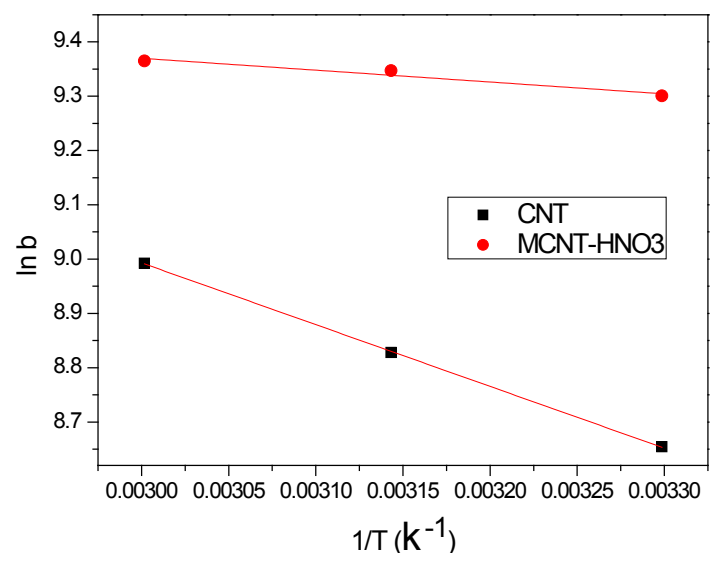

Figure 10: Van't Hoff isotherm for adsorption of Cd(II) on CNT and MCNT-HNO .

\begin{tabular}{|l|c|c|l|l|l|l|}
\hline & \multicolumn{3}{|c|}{ CNT } & \multicolumn{3}{c|}{ MCNT-HNO } \\
\hline $\mathbf{T}(\mathbf{K})$ & 303.15 & 318.15 & 333.15 & 303.15 & 318.15 & 333.15 \\
\hline $\mathbf{\Delta G}^{\mathbf{0}}(\mathbf{K J} / \mathbf{m o l})$ & -21.81 & -23.35 & -24.91 & -23.44 & -24.72 & -25.94 \\
\hline $\mathbf{\Delta H}^{\mathbf{0}}(\mathbf{K J} / \mathbf{m o l})$ & \multicolumn{3}{|c|}{9.456} & \multicolumn{3}{c|}{1.816} \\
\hline $\left.\mathbf{\Delta S}^{\mathbf{0}} \mathbf{( J / m o l} / \mathbf{k}\right)$ & \multicolumn{3}{|c|}{103.14} & \multicolumn{3}{c|}{83.34} \\
\hline
\end{tabular}

Table 5: Thermodynamic parameters for the adsorption of $\mathrm{Pb}$ (II) on CNT and $\mathrm{MCNT}-\mathrm{HNO}_{3}$.

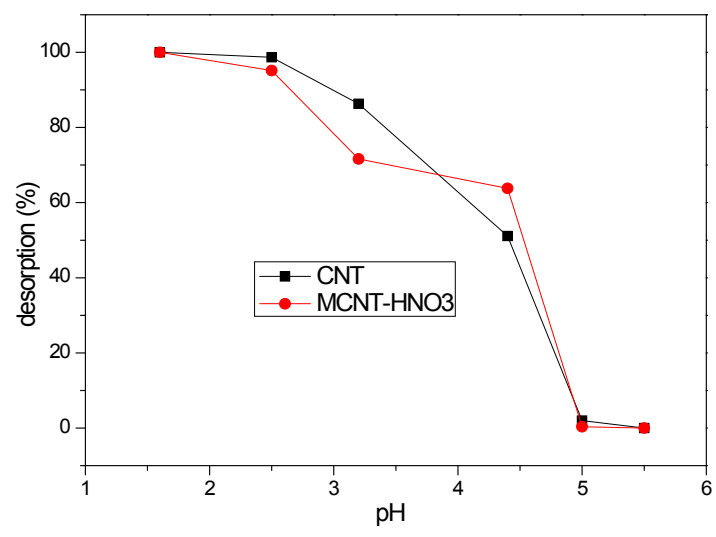

Figure 11: Desorption of $\mathrm{Cd}(\mathrm{II})$ from $\mathrm{CNT}$ and $\mathrm{MCNT}-\mathrm{HNO}_{3}$ by adjusting the $\mathrm{pH}$ values of the solution using $\mathrm{HCl}$.

process. The positive values of $\Delta S^{\circ}$ reflect the affinity of the carbons for $\mathrm{Cd}(\mathrm{II})$ and also suggest some structural changes in the adsorbate and adsorbent.

Desorption studies: Reversibility, which decides the cost of adsorption to some extent, is very important for the practical application of an adsorbent. An advanced adsorbent should possess both higher adsorption capacity and better desorption property. Figure 11 shows the cadmium (II) desorption percentages with regard to solutions at various $\mathrm{pH}$ values. It is apparent that the Cadmium (II) desorption percentages increased with a decrease of the $\mathrm{pH}$ value of the solution. The percentage of desorption increased sharply from $\mathrm{pH} 5$ to $\mathrm{pH}=2.5$ and eventually reached about $100 \%$ at $\mathrm{pH}=1.6$. The above results show that the $\mathrm{Cd}(\mathrm{II})$ adsorbed by the carbons can be easily desorbed and can be employed repeatedly in heavy-metal water purification. Furthermore, the regeneration process also indicates that ion exchange is one of the main adsorption mechanisms.

\section{Conclusion}

Modification of $\mathrm{CNT}$ by $\mathrm{HNO}_{3}$ increased the number of oxygencontaining groups on the surface of CNT with increase in surface area. The adsorption of Cd (II) was dependent on $\mathrm{pH}$, adsorbate concentration, contact time, temperature and adsorbent dose. The adsorbed amounts at equilibrium by $\mathrm{MCNT}-\mathrm{HNO}_{3}$ were estimated to be almost 2.34 times as much as the capacity by CNT. Langmuir adsorption model provides the best fit with experimentally obtained data for CNT and MCNT- $\mathrm{HNO}_{3}$. The kinetics of adsorption of Cd(II) on both sorbents follows the pseudo second-order. The rate-controlling step of adsorption process was affected by both intraparticle diffusion and film diffusion for $\mathrm{CNT}$ and $\mathrm{MCNT}-\mathrm{HNO}_{3}$. The negative values of $\Delta \mathrm{G}^{\circ}$ indicated the spontaneous nature of the process. MCNT- $\mathrm{HNO}_{3}$ showed a good removal efficiency of Cd(II) from water at low sorbent dose. The desorption studies revealed that the regeneration of MCNT$\mathrm{HNO}_{3}$ can be easily achieved.

\section{Acknowledgments}

The author(s) would like to acknowledge the support provided by The Academy of Scientific Research and Technology (ASRT) of Egypt.

\section{References}

1. (2011) ATSDR, Priority List of Hazardous Substances.

2. Kadirvelu K, Thamaraiselvi K, Namasivayam C (2001) Removal of heavy metals from industrial wastewaters by adsorption onto activated carbon prepared from an agricultural solid waste. Bioresour Technol 76: 63-65. 
Citation: AkI MA, Abou-Elanwar AM (2015) Adsorption Studies of Cd (II) from Water by Acid Modified Multiwalled Carbon Nanotubes. J Nanomed Nanotechnol 6: 327. doi:10.4172/2157-7439.1000327

3. Baes CF, Mesmer RE (1976) The hydrolysis of cations 68, Wiley New York.

4. (2009) USEPA. National Primary Drinking Water Regulations.

5. Cadmium C, Nickel N (2007) Monitored Natural Attenuation of Inorganic Contaminants in Ground Water.

6. Organization WH (2011) Guidelines for drinking-water quality (4thedn), World Health Organization.

7. Mahmoud ME (2010) Performance evaluation of hybrid inorganic/organic adsorbents in removal and preconcentration of heavy metals from drinking and industrial waste water. Desalination 253: 9-15.

8. Tian Y (2010) Removal of transition metal ions from aqueous solutions by adsorption using a novel hybrid material silica gel chemically modified by triethylene tetramino methylene phosphonic acid. Chemical Engineering Journal 162: 573-579.

9. lijima S (1991) Helical microtubules of graphitic carbon. Nature 354: 56-58.

10. Treacy MMJ, Ebbesen TW, Gibson JM (1996) Exceptionally high Young's modulus observed for individual carbon nanotubes. Nature 381: 678-680.

11. Ebbesen W, Lezec HJ, Hiura H, Bennett JW, Ghaemi HF, et al. (1996) Electrica conductivity of individual carbon nanotubes. Nature 382: 54-56.

12. Peigney A, Laurent CH, Flahaut E, Bacsa RR, Rousset A (2001) Specific surface area of carbon nanotubes and bundles of carbon nanotubes. Carbon 4: 507-514.

13. Qian L, Yang X (2006) Preparation of cobalt hexacyanoferrate nanowires using carbon nanotubes as templates. Talanta 69: 957-962.

14. Li W (2002) Carbon nanotubes as support for cathode catalyst of a direct methanol fuel cell. Carbon 5: 791-794.

15. Niu L, Luo Y, Li Z (2007) A highly selective chemical gas sensor based on functionalization of multi-walled carbon nanotubes with poly (ethylene glycol). Sensors and Actuators B: Chemical 126: 361-367.

16. Rakhi R, Sethupathi K, Ramaprabhu S (2008) Synthesis and hydrogen storage properties of carbon nanotubes. International Journal of Hydrogen Energy 33: 381-386.

17. $\mathrm{Wu} \mathrm{CH}$ (2007) Studies of the equilibrium and thermodynamics of the adsorption of $\mathrm{Cu}(2+)$ onto as-produced and modified carbon nanotubes. J Colloid Interface Sci 311: 338-346.

18. Li YH, Wang S, Luan Z, Ding J, Xu C, et al. (2003) Adsorption of Cd(II) from aqueous solution by surface oxidized carbon nanotubes. Carbon 41: 10571062.

19. Yan XM, Shi BY, Lu JJ, Feng CH, Wang DS, et al. (2008) Adsorption and desorption of atrazine on carbon nanotubes. J Colloid Interface Sci 321: 30-38.

20. Chen W, Duan L, Zhu D (2007) Adsorption of polar and nonpolar organic chemicals to carbon nanotubes. Environ Sci Technol 41: 8295-8300.

21. Chen C, Hu J, Xu D, Tan X, Meng Y, et al. (2008) Surface complexation modeling of $\mathrm{Sr}(\mathrm{II})$ and $\mathrm{Eu}(\mathrm{III})$ adsorption onto oxidized multiwall carbon nanotubes. J Colloid Interface Sci 323: 33-41.

22. Wang X, Chen C, Hu W, Ding A, Xu D, et al. (2005) Sorption of 243Am(III) to multiwall carbon nanotubes. Environ Sci Technol 39: 2856-2860.

23. Goertzen SL, Kim D, Oickle AM, Anthony C, et al. (2010) Standardization of the Boehm titration. Part I $\mathrm{CO}_{2}$ expulsion and endpoint determination. Carbon 48: $1252-1261$

24. Boehm HP (1994) Some aspects of the surface chemistry of carbon blacks and other carbons. Carbon 32: 759-769.

25. Boehm HP (1996) Chemical Identification of Surface Groups, in Advances in Catalysis, HPDD Eley and BW Paul, Editors. Academic Press 179-274.

26. Rivera-Utrilla J (2001) Activated carbon surface modifications by adsorption of bacteria and their effect on aqueous lead adsorption. Journal of Chemical Technology \& Biotechnology 76: 1209-1215.

27. Youssef AM (2013) EDTA Versus Nitric Acid Modified Activated Carbon For Adsorption Studies of Lead (II) From Aqueous Solutions. Journal of Applied Sciences Research 9: 16.

28. Brunauer S, Emmett PH, Teller E (1938) Adsorption of Gases in Multimolecular Layers. Journal of the American Chemical Society 60: 309-319.
29. Selles-Perez MJ, Martin-Martinez JM (1991) Application of $\alpha$ and $n$ plots to N2 adsorption isotherms of activated carbons. Journal of the Chemical Society, Faraday Transactions 87: 1237-1243.

30. Kennedy LJ, Vijaya JJ, Sekaran G (2005) Electrical conductivity study of porous carbon composite derived from rice husk. Materials Chemistry and Physics 91: 471-476.

31. Kennedy LJ, Vijaya JJ, Sekaran G (2004) Effect of Two-Stage Process on the Preparation and Characterization of Porous Carbon Composite from Rice Husk by Phosphoric Acid Activation. Industrial \& Engineering Chemistry Research 43: $1832-1838$

32. Lu C, Chung YL, Chang KF (2005) Adsorption of trihalomethanes from water with carbon nanotubes. Water Res 39: 1183-1189.

33. Li YH, Xu C, Wei B, Zhang X, Zheng M, et al. (2002) Self-organized ribbons of aligned carbon nanotubes. Chemistry of materials 14: 483-485.

34. Brunauer S (1940) On a Theory of the van der Waals Adsorption of Gases Journal of the American Chemical Society 62: 1723-1732.

35. Tsang SC, Chen YK, Harris PJF, Green MLH (1994) A simple chemical method of opening and filling carbon nanotubes. Nature 372: 159-162.

36. Banerjee S, Hemraj-Benny T, Wong SS (2005) Covalent surface chemistry of single-walled carbon nanotubes. Advanced Materials 17: 17-29.

37. Ruelle B, Peeterbroeck S, Gouttebaron R, Godfroid T, Monteverde F, et al (2007) Functionalization of carbon nanotubes by atomic nitrogen formed in a microwave plasma $\mathrm{Ar}+\mathrm{N}_{2}$ and subsequent poly grafting. Journal of Materials Chemistry 17: 157-159.

38. Ozacar M, Sengil IA (2005) Adsorption of metal complex dyes from aqueous solutions by pine sawdust. Bioresour Technol 96: 791-795.

39. Sun G, Xu X (1997) Sunflower Stalks as Adsorbents for Color Removal from Textile Wastewater. Industrial \& Engineering Chemistry Research 36: 808-812.

40. Yu LJ, Shukla SS, Dorris KL, Shukla A, Margrave JL (2003) Adsorption of chromium from aqueous solutions by maple sawdust. J Hazard Mater 100: 5363.

41. Shukla A, Zhang YH, Dubey P, Margrave JL, Shukla SS (2002) The role of sawdust in the removal of unwanted materials from water. $J$ Hazard Mater 95: 137-152.

42. Ania CO, Parra JB, Pis JJ (2002) Influence of oxygen-containing functiona groups on active carbon adsorption of selected organic compounds. Fuel Processing Technology 79: 265-271.

43. Karagoz S, Tay T, Ucar S, Erdem M (2008) Activated carbons from waste biomass by sulfuric acid activation and their use on methylene blue adsorption. Bioresour Technol 99: 6214-6222.

44. Chilton N, Lossob JN, Marshall WE, Rao RM (2002) Freundlich adsorption isotherms of agricultural by-product-based powdered activated carbons in a geosmin-water system. Bioresource Technology: 131-135.

45. Hameed BH, Ahmad AL, Latiff KNA (2007) Adsorption of basic dye (methylene blue) onto activated carbon prepared from rattan sawdust. Dyes and Pigments 75: $143-149$

46. Franca AS, Oliveira LS, Ferreira ME (2009) Kinetics and equilibrium studies of methylene blue adsorption by spent coffee grounds. Desalination 249 267-272.

47. Ozacar M (2003) Equilibrium and kinetic modelling of adsorption of phosphorus on calcined alunite. Adsorption 9: 125-132.

48. Wu FC, Tseng RL, Juang RS (2001) Adsorption of dyes and phenols from water on the activated carbons prepared from corncob wastes. Environ Technol 22 205-213.

49. Annadurai G, Juang RS, Lee DJ (2002) Use of cellulose-based wastes for adsorption of dyes from aqueous solutions. J Hazard Mater 92: 263-274.

50. Altenor S, Carene B, Emmanuel E, Lambert J, Ehrhardt JJ, et al. (2009) Adsorption studies of methylene blue and phenol onto vetiver roots activated carbon prepared by chemical activation. J Hazard Mater 165: 1029-1039.

51. Qi L, Xu Z (2004) Lead sorption from aqueous solutions on chitosan nanoparticles. Colloids and Surfaces A: Physicochemical and Engineering Aspects 251: 183-190. 
Citation: Akl MA, Abou-Elanwar AM (2015) Adsorption Studies of Cd (II) from Water by Acid Modified Multiwalled Carbon Nanotubes. J Nanomed Nanotechnol 6: 327. doi:10.4172/2157-7439.1000327

52. Yan G, Viraraghavan T (2003) Heavy-metal removal from aqueous solution by fungus Mucor rouxii. Water Res 37: 4486-4496.

53. Boyd GE, Adamson AW, Myers LS (1947) The Exchange Adsorption of lons from Aqueous Solutions by Organic Zeolites. II Kinetics1. Journal of the American Chemical Society 69: 2836-2848.
54. Reichenberg D (1953) Properties of Ion-exchange Resins in Relation to their Structure. III. Kinetics of Exchange. Journal of the American Chemical Society 75: 589-597. 